INT. J. RADIAT. BIOL 2000, VOL. 76, NO. 7, 955-961

\title{
Chromosomal aberrations and hprt mutant frequencies in long-term American thorotrast survivors
}

\author{
E. A. PLATZ*, J. K. WIENGKE $\dagger$, K. T. KELSEY $\ddagger$, M. L. JANOWER \\ D. SCHOTTENFELD $\uparrow$, L. B. TRAVIS $\|$ and M. B. GOLDMAN**
}

(Received 22 September 1999; accepted 14 January 2000)

\begin{abstract}
.
Purpose: Patients injected with thorotrast, a radiologic contrast medium used from the 1920 s to early 1950 s, received chronic internal exposure to thorium-232, an $\alpha$-emitter. Epidemiologic studies have observed markedly elevated risks of death from hepatic and hematologic cancers and extensive chromosomal damage among these patients. Few investigations have correlated multiple measures of genetic damage to determine whether these have independent induction kinetics. The distribution of chromosomal aberrations (CA) and mutant frequencies (MF) at the hypoxanthine phosphoribosyltransferase (hprt) locus was evaluated in eight long-term thorotrast survivors (mean exposure time $=47.4$ years) and five individuals who received a nonradioactive contrast medium during the same era.

Materials and methods: Peripheral blood lymphocytes were harvested from whole blood, CA were scored in 500 complete metaphases and a clonal assay was used to determine hprt MF. Symmetrical aberrations were not evaluated. Differences in frequencies and correlations between endpoints were assessed using nonparametric methods.

Results: Thorotrast-exposed individuals differed from the comparison group in total number of multicentrics and centric and acentric rings (per 500 cells [median, mean $\pm \mathrm{sd}$ ]: 11, 18.3 \pm 23.1 vs $2,2.4 \pm 1.1, p=0.04)$. There was no difference between the groups on hprt MF (12.6, $15.9 \pm 13.5$ vs 16.6, $14.0 \pm 8.8\left[\times 10^{-6}\right]$; $p=1.0)$. Among the exposed, $h p r t \mathrm{MF}$ was moderately correlated with the frequency of asymmetrical chromosomal aberrations, although the association was not statistically significant.

Conclusion: Noting the limitations of small samples, long-term
\end{abstract}

*Author for correspondence.

Department of Nutrition, Harvard School of Public Health, Boston, MA 02115, USA. Address for correspondence: Department of Epidemiology, Johns Hopkins School of Hygiene and Public Health, 615 North Wolfe Street, Baltimore, MD 21205, USA. E-mail: @jhsph.edu.

$\uparrow$ Laboratory for Molecular Epidemiology, Department of Epidemiology and Biostatistics, University of California, San Francisco, CA 94143, USA.

¡Department of Cancer Cell Biology, Harvard School of Public Health, Boston, MA 02115, USA.

$\S$ Department of Radiology, Saint Vincent Hospital, Worcester, MA 01604, USA.

『Department of Epidemiology, University of Michigan School of Public Health, Ann Arbor, MI 48109.

\| Division of Cancer Epidemiology and Genetics, National Cancer Institute, National Institutes of Health, Bethesda, MD 20892.

**Department of Epidemiology, Harvard School of Public Health, Boston, MA 02115. thorotrast survivors were observed to be at an increased risk for genetic damage.

\section{Introduction}

Patients injected with thorotrast, a contrast medium used worldwide from the 1920 s to the early 1950 s to enhance the quality of diagnostic radiographs, received chronic internal exposure to thorium-232, a naturally occurring $\alpha$-emitter (Travis $e t$ al. 1992). Macrophages engulf and distribute thorotrast to organs of the reticuloendothelial system, including the liver, spleen and bone marrow (Kaul and Noffz 1978). These patients' cells experience ongoing exposure to $\alpha$-particles leading to the continual development of chromosomal damage and cell killing.

Epidemiologic studies have observed a markedly elevated incidence of and mortality from hepatic and hematologic cancers among Thorotrast-exposed patients (da Motta et al. 1979, Mori et al. 1983, van Kaick et al. 1983, van Kaick et al. 1991, Andersson and Storm 1992, Andersson et al. 1994, Andersson et al. 1995, Goldman et al. 1997). Extensive chromosomal aberrations and sister-chromatid exchanges have been reported in peripheral blood lymphocytes from thorotrast survivors (Fischer et al. 1966, Buckton et al. 1967, Fischer and Golob 1967, Kemmer et al. 1971, Janower et al. 1972, Ishihara et al. 1978, Teixeira-Pinto and Azevedo e Silva 1979, Steinstrasser 1981a,b, Sasaki et al. 1987). Among 25 members of the American cohort who were examined in the early 1970s, the average number of chromosomal breaks (rings, dicentrics and rearrangements counted as two breaks and fragments as one break) was 34 per 100 cells (Janower et al. 1972). The proportion among the comparison group was 2 per 100 cells.

Characteristic of high linear-energy-transfer radiation, the extent of chromosomal damage per peripheral blood lymphocyte from thorotrast patients is greater than would be expected based on the Poisson distribution (Sasaki et al. 1987). Clear dose-response relationships between absorbed dose of radiation and 
number of chromosomal abnormalities generally have not been observed (Kemmer et al. 1979), possibly because of the complex relationship between chromosomal damage and cell killing. Whether various mechanisms of genetic damage in thorotrast-exposed individuals have independent induction kinetics has not been addressed.

Presented in this report is the distribution of chromosomal aberrations and mutant frequencies at the hypoxanthine phosphoribosyltransferase (hprt) locus in peripheral blood lymphocytes from eight long-term American thorotrast survivors (mean exposure time $=47.4$ years) and five individuals who underwent similar diagnostic procedures with a nonradioactive contrast medium during the same era. In addition, correlations among specific types of chromosomal aberrations and hprt mutant frequency are assessed.

\section{Materials and methods}

\subsection{Study population}

Participants were identified from among members of the American thorotrast cohort. Cohort members were men and women who underwent cerebral angiography with intravascular administration of thorotrast for neurological indications from the late 1930s to the early 1950 s at one of three hospitals and were originally identified in the 1960s through medical record review as described previously (Janower $e t$ al. 1972). Patients who underwent angiography with diodrast, a nonradioactive contrast medium, for similar indications in the late 1940s and early 1950s were also identified. A total of 723 thorotrast and 315 diodrast patients were ascertained.

With follow-up through 1995, current vital status was known for $92 \%$; of these $90 \%$ of the thorotrast and $75 \%$ of the diodrast group were deceased (Goldman et al. 1997). Surviving cohort members were identified through motor vehicle registries, town censuses, and telephone books. As they were identified, surviving cohort members were contacted by mail or telephone to invite them to provide a blood sample for this substudy. Eight of 11 people with thorotrast exposure and five of six with diodrast exposure who were invited to participate agreed and successfully provided a blood sample between November 1993 and November 1994. Venous blood was drawn into 10-ml tubes containing sodium EDTA and was processed immediately for the hprt mutant frequency assay in the laboratory of Dr Kelsey or shipped by overnight courier at room temperature in an insulated biohazard container to the laboratory of Dr Wiencke for evaluation of aberrations.

\subsection{Chromosomal aberrations}

Within $36 \mathrm{~h}$ of blood drawing, whole blood $(0.5 \mathrm{ml})$ was added to $4.5 \mathrm{ml}$ of RPMI 1640 medium containing $10 \%$ fetal calf serum, $2 \mathrm{~mm}$ glutamine, 100 units $/ \mathrm{ml}$ penicillin, $100 \mathrm{mg} / \mathrm{ml}$ streptomycin, and $2 \%$ phytohemagglutinin $\mathrm{M}$ (Gibco). The blood was cultured at $37^{\circ} \mathrm{C}$ in $1-\mathrm{oz}$ glass prescription bottles for $48 \mathrm{~h}$. Colcemid (final concentration $2 \times 10^{-7} \mathrm{M}$ ) was added to arrest cells in mitosis and cells were harvested $2 \mathrm{~h}$ later. Fixation was performed by standard cytological procedures; the cells were exposed to a $0.075 \mathrm{M} \mathrm{KCl}$ solution for $8 \mathrm{~min}$ to spread chromosomes and then fixed in a methanol-acetic acid solution (3:1). Cytological preparations were made by placing cells on wet slides and staining with Giemsa. Chromosomal aberrations were scored in 500 complete metaphases (300 for one participant). Aberration data were not available for one thorotrast participant. Scored were chromatid aberrations, including chromatid deletions and isochromatid deletions, and asymmetrical chromosome aberrations, including tricentrics, dicentrics, centric rings, acentric rings, interstitial deletions and terminal deletions. Chromatid gaps, defined as achromatic lesions less than the width of the chromatid were not recorded. To obtain an overall measure of unstable damage, the sum of centric rings, acentric rings, dicentrics and tricentrics, which were counted as two dicentrics each, were calculated. To calculate the number of terminal deletions that was not the result of multicentric formation, the number of dicentrics and twice the number of tricentrics were subtracted from the observed number of terminal deletions. If the number of multicentrics exceeded the number of terminal deletions, the remaining excess was subtracted from the number of interstitial deletions. The blood samples were received coded and the cells were scored without knowledge of the participant's exposure status.

\subsection{Hprt mutant frequency}

Mononuclear cells were isolated from peripheral blood by Ficoll-Hypaque separation medium. After washing the cells twice with Earle's balanced salt solution (EBSS), they were placed in a culture medium [RPMI 1640, 20\% HL-1, 10\% fetal bovine serum (Hyclone), penicillin (100 units/ml), and streptomycin $(100 \mu \mathrm{g} / \mathrm{ml})]$ along with $1 \mu \mathrm{g} / \mathrm{ml}$ of phytohemagglutinin (Burroughs-Wellcome). The cultures were kept in $5 \% \mathrm{CO}_{2}$ at $37^{\circ} \mathrm{C}$ for $40 \mathrm{~h}$. The cells were counted on a hemacytometer and plated in a culture medium (same composition as above) with the addition of $0.125 \mu \mathrm{g} / \mathrm{ml}$ phytohemagglutinin 
and 20\% T-cell growth factor. The T-cell growth factor was derived from the supernatant of lymphokine-activated killer cells and was generously provided by Drs Timothy Eberlein and Deric D. Schoof (Brigham and Women's Hospital, Boston, MA, USA) and Dr Michael Atkins (Tufts University Medical School, Boston, MA, USA). Feeder cells, which were TK-6 human B-lymphoblastoid cells irradiated at $5000 \mathrm{cGy}$, were added at a concentration of $1 \times 10^{4}$ cells in culture medium to each microtiter well. Using serial dilution, $2 \times 10^{4}$ lymphocytes were plated into each well along with 6 -thioguanine $(20 \mu \mathrm{M})$ as the selective agent. 2, 5 and 10 lymphocytes per well were also plated without the selective agent to assess cloning efficiency. After 14 days, the plates were scored by one reader blinded to the participants' exposure status. The cloning efficiency was estimated assuming a Poisson distribution $\left(P_{\mathrm{o}}=\mathrm{e}^{-x}\right)$ : cloning efficiency $=-[\ln ($ fraction negative cells $)] /$ (number of cells per well). The mutant frequency was calculated as the ratio of the cloning efficiency with the selective agent to the cloning efficiency without the selective agent. Hprt mutant frequency was not available for two thorotrast participants due to poor cloning efficiency and technical problems.

\subsection{Statistical analysis}

Differences in the frequency of chromosomal aberrations expressed per 500 cells scored and hprt mutant frequency by thorotrast exposure status were evaluated using the nonparametric Wilcoxon rank sum test (Rosner 1986). Nonparametric Spearman correlation coefficients were calculated for the interrelations among the specific aberrations, hprt mutant frequency, volume of thorotrast, and duration of exposure to thorotrast among the thorotrast-exposed individuals (Rosner 1986). Using the $\chi^{2}$ test for goodness of fit (Rosner 1986), we evaluated whether the observed distribution of unstable damage was consistent with the Poisson distribution or the 0truncated Poisson distribution, which was previously reported to describe the overdispersion of the number of cells with multiple aberrations associated with internal exposure to thorotrast and $\alpha$-particles (Sasaki et al. 1987). Analyses were conducted using SAS version 6.12 (SAS Institute, Cary, NG, USA) statistical software.

\section{Results}

Eight thorotrast and five diodrast survivors provided blood samples. The mean age at which the contrast media were administered was $22.9 \pm 5.1$ years for thorotrast patients and $24.6 \pm 6.4$ years for diodrast patients; the mean ages at which blood for these analyses was drawn were similar for the two groups (thorotrast: 70.2 \pm 5.0 years; diodrast: $69.0 \pm 7.8$ years). The volume of thorotrast injected ranged from $5 \mathrm{ml}$ to $40 \mathrm{ml}$ among the six survivors for whom volume was recorded in their medical records. Demographic features and the distribution of asymmetrical chromosome and chromatid aberrations are summarized for each participant in table 1 .

A total of 3300 and 2500 cells were scored for thorotrast and diodrast participants, respectively. Thorotrast survivors showed a higher frequency of asymmetrical chromosome, but not chromatid aberrations (table 2). In particular, the frequency of multicentrics (dicentrics plus tricentrics) was statistically significantly $(p=0.03)$ greater in the thorotrast group (median, mean \pm sd: $11,15.8 \pm 19.0$ per 500 cells) compared to the diodrast group $(2,1.6 \pm 0.5$ per 500 cells). Combining multicentrics and rings to represent unstable aberrations, the frequency differed between the two groups $(p=0.04)$ and ranged from 0.002 to 0.138 per cell $(11,18.3 \pm 23.1$ per 500 cells $)$ among the thorotrast exposed and 0.002 to 0.008 per cell (2, $2.4 \pm 1.1$ per 500 cells) among the diodrast exposed. The frequency of multicentrics and rings were moderately correlated (Spearman $r=0.69, p=$ 0.08) in those with thorotrast exposure. Among the thorotrast-exposed participants, generally there was little evidence for positive correlations between asymmetrical chromosome aberrations and volume injected or duration of exposure. Across the volume range of 5-40 $\mathrm{ml}$ for the six Thorotrast-exposed individuals with known volume, the observed number of centric rings increased from 0 to 2 per 500 cells (Spearman $r=0.9, p=0.008$ ).

The distribution of multicentrics and rings among the thorotrast survivors was overdispersed relative to the Poisson distribution $(p=0.03)$, while the distribution among the diodrast group was not inconsistent with the Poisson distribution (table 3). The distribution of unstable aberrations among those exposed to thorotrast was not inconsistent with the 0 -truncated Poisson distribution $(p=0.5)$. Possibly because of the small number of thorotrast survivors in the study, there was a deficit of cells with three aberrations and an excess of cells with four aberrations when compared to what would be expected under the 0-truncated Poisson distribution.

The hprt mutant frequency did not differ between the thorotrast and diodrast survivors $(p=1.0)$ (table 4). The cloning efficiency was somewhat lower among the thorotrast group, however, cloning efficiency and $h p r t$ mutant frequency were not correlated $(r=-0.05, p=0.9)$. Among five Thorotrast survivors with complete data, hprt mutant frequency was 
Table 1. Participant characteristics and frequency of asymmetrical chromosome and chromatid aberrations among long-term American thorotrast $(n=8)$ and diodrast $(n=5)$ survivors.

\begin{tabular}{|c|c|c|c|c|c|c|c|c|c|c|c|c|c|}
\hline \multirow[b]{3}{*}{ ID } & \multirow{3}{*}{$\begin{array}{l}\text { Volume of } \\
\text { thorotrast } \\
(\mathrm{ml})\end{array}$} & \multirow{3}{*}{$\begin{array}{c}\text { Age at } \\
\text { injection } \\
\text { (years) }\end{array}$} & \multirow{3}{*}{$\begin{array}{c}\text { Age at } \\
\text { evaluation } \\
\text { (years) }\end{array}$} & \multirow[b]{3}{*}{ Sex } & \multirow{3}{*}{$\begin{array}{c}\text { Cells } \\
\text { (no.) }\end{array}$} & \multicolumn{8}{|c|}{ Aberrations } \\
\hline & & & & & & \multicolumn{4}{|c|}{ Chromosome } & \multicolumn{4}{|c|}{ Chromatid } \\
\hline & & & & & & Tri & Dic & $\mathrm{Rc}$ & $\mathrm{Ra}$ & ID & $\mathrm{TD}$ & $\mathrm{CD}$ & Iso \\
\hline 1 & 16 & 20 & 64 & $\mathrm{~F}$ & 500 & 2 & 13 & 1 & 1 & 15 & 10 & 11 & 0 \\
\hline $2^{*}$ & Unknown & 29 & 77 & $\mathrm{~F}$ & - & - & - & - & - & - & - & - & - \\
\hline 3 & 10 & 18 & 63 & M & 500 & 0 & 1 & 0 & 0 & 0 & 8 & 14 & 6 \\
\hline 4 & 14 & 23 & 71 & M & 300 & 0 & 5 & 0 & 0 & 8 & 0 & 13 & 6 \\
\hline 5 & 24 & 25 & 74 & $\mathrm{~F}$ & 500 & 0 & 3 & 2 & 0 & 0 & 12 & 4 & 0 \\
\hline 6 & 40 & 17 & 69 & $\mathrm{M}$ & 500 & 1 & 11 & 2 & 0 & 6 & 0 & 4 & 0 \\
\hline 7 & Unknown & 31 & 75 & $\mathrm{~F}$ & 500 & 3 & 51 & $1 \overline{1}$ & 1 & 93 & 35 & 2 & 0 \\
\hline 8 & 5 & 20 & 69 & $\mathrm{~F}$ & 500 & 1 & 9 & 0 & 0 & 8 & 10 & 2 & 0 \\
\hline 9 & 0 & 19 & 64 & $\mathrm{~F}$ & 500 & 0 & 1 & 0 & 1 & 18 & 12 & 3 & 0 \\
\hline 10 & 0 & 29 & 75 & M & 500 & 0 & 2 & 1 & 0 & 7 & 0 & 10 & $5 \dagger$ \\
\hline 11 & 0 & 17 & 59 & M & 500 & 0 & 2 & 0 & 2 & 5 & 7 & 4 & 0 \\
\hline 12 & 0 & 26 & 69 & M & 500 & 0 & 2 & 0 & 0 & 1 & 14 & 3 & 0 \\
\hline 13 & 0 & 32 & 78 & $\mathrm{~F}$ & 500 & 0 & 1 & 0 & 0 & 0 & 2 & 4 & 0 \\
\hline
\end{tabular}

Abbreviations: $\mathrm{T}=$ thorotrast, $\mathrm{D}=$ diodrast, $\mathrm{F}=$ female, $\mathrm{M}=$ male, Tri $=$ tricentrics, $\mathrm{Dic}=$ dicentrics, $\mathrm{Rc}=$ centric rings, $\mathrm{Ra}=\mathrm{acentric}$ rings, $\mathrm{ID}=$ interstitial deletions, $\mathrm{TD}=$ terminal deletions, $\mathrm{CD}=$ chromatid deletions and $\mathrm{Iso}=$ isochromatid deletions.

* Aberration data not available.

$\dagger$ Individual also had two chromatid exchanges.

Table 2. Mean number of asymmetrical chromosome and chromatid aberrations per 500 metaphases scored among long-term American thorotrast $(n=7)$ and diodrast $(n=5)$ survivors.

\begin{tabular}{|c|c|c|c|c|c|c|c|}
\hline \multirow[b]{2}{*}{ Aberration } & \multicolumn{3}{|c|}{ Thorotrast } & \multicolumn{3}{|c|}{ Diodrast } & \multirow[b]{2}{*}{$p^{*}$} \\
\hline & Median & Mean & SD & Median & Mean & $\mathrm{SD}$ & \\
\hline \multicolumn{8}{|l|}{ Chromosome } \\
\hline Tricentrics & 1 & 1.0 & 1.2 & 0 & 0.0 & 0.0 & 0.07 \\
\hline Dicentrics & 9 & 13.8 & 17.0 & 2 & 1.6 & 0.5 & 0.03 \\
\hline Centric rings & 1 & 2.3 & 3.9 & 0 & 0.2 & 0.4 & 0.2 \\
\hline Acentric rings & 0 & 0.3 & 0.5 & 0 & 0.6 & 0.9 & 0.6 \\
\hline Dicentrics plus rings $\dagger$ & 11 & 18.3 & 23.1 & 2 & 2.4 & 1.1 & 0.04 \\
\hline Interstitial deletions & 8 & 19.3 & 33.0 & 5 & 6.2 & 7.2 & 0.6 \\
\hline Terminal deletions & 10 & 10.7 & 11.8 & 7 & 7.0 & 6.1 & 0.9 \\
\hline Total chromosome aberrations & 22 & 47.4 & 65.5 & 16 & 15.6 & 10.7 & 0.2 \\
\hline \multicolumn{8}{|l|}{ Chromatid } \\
\hline Chromatid deletions & 4 & 8.4 & 7.5 & 4 & 4.8 & 2.9 & 0.6 \\
\hline Isochromatid deletions & 0 & 2.3 & 4.1 & 0 & 1.0 & 2.2 & 0.7 \\
\hline Exchanges & 0 & 0.0 & 0.0 & 0 & 0.4 & 0.9 & 0.3 \\
\hline Total chromatid aberrations & 4 & 10.7 & 11.3 & 4 & 6.2 & 6.1 & 0.7 \\
\hline
\end{tabular}

*From the nonparametric Wilcoxon rank sum test.

$\uparrow$ Sum of centric rings, acentric rings, dicentrics and tricentrics (counted as two dicentrics each).

moderately, but statistically not significantly, positively correlated with multicentrics (Spearman $r=0.60$, $p=0.3)$. Hprt mutant frequency was not correlated with rings (Spearman $r=-0.05, P=0.9$ ).

\section{Discussion}

We evaluated the frequency of chromosomal aberrations and the hprt mutant frequency in a small sample of American men and women with 44-52 years of internal exposure to $\alpha$-particles from the contrast medium thorotrast. Compared to similarly aged participants, who also underwent cerebral angiography with a nonradioactive contrast medium during the same era, the frequency of asymmetrical chromosome, but not chromatid, aberrations was elevated, in particular dicentrics and tricentrics. Thorotrast-exposed participants did not differ from the comparison group with regard to hprt mutant frequency. 
Table 3. Number of cells with a given number of dicentrics and rings among long-term American thorotrast $(n=7)$ and diodrast $(n=5)$ survivors.

\begin{tabular}{|c|c|c|c|c|c|c|c|c|c|c|}
\hline \multirow[b]{2}{*}{ Contrast } & \multirow{2}{*}{$\begin{array}{l}\text { Total } \\
\text { cells }\end{array}$} & \multicolumn{5}{|c|}{$\begin{array}{l}\text { No. cells with given number of } \\
\text { dicentrics and rings }\end{array}$} & \multirow[b]{2}{*}{ Mean } & \multirow[b]{2}{*}{ Variance } & \multirow{2}{*}{$\begin{array}{l}\text { Index of } \\
\text { dispersion }\end{array}$} & \multirow[b]{2}{*}{$p \S$} \\
\hline & & 0 & 1 & 2 & 3 & 4 & & & & \\
\hline \multicolumn{11}{|l|}{ Thorotrast } \\
\hline Observed & 3300 & 3182 & 73 & 15 & 1 & 3 & 0.036 & 0.056 & 1.56 & \\
\hline Expected* & & 3184.1 & 113.9 & 2.0 & 0.02 & 0.0002 & & & & 0.03 \\
\hline Expected $\dagger$ & 226.9 व & 134.9 & 70.1 & 18.2 & 3.2 & 0.4 & 0.52 & & & $0.5 \|$ \\
\hline \multicolumn{11}{|l|}{ Diodrast } \\
\hline Observed & 2500 & 2488 & 12 & 0 & 0 & 0 & 0.005 & 0.005 & 0.96 & \\
\hline Expected* & & 2488.0 & 11.9 & 0.03 & 0.0001 & 0 & & & & 1.0 \\
\hline
\end{tabular}

*The expected frequencies of cells with 0 or 1 or more aberrations was estimated by multiplying the number of cells scored by the probability of observing a given number of aberrations per cell predicted from the Poisson distribution; $\operatorname{Pr}(X=k)=\mu^{k} \exp (-\mu) / k$ ! where $\mu=$ mean number of aberrations per cell and $k=$ number of aberrations per cell.

$\dagger$ The mean number of aberrations among the exposed cells was estimated from $-\mu \mathcal{N}-X \exp (-\mu)+X=0$, where $\mu=$ mean number of aberrations among the exposed cells, $\mathcal{N}=$ the number of observed cells with at least one aberration and $X$ is the total number of observed aberrations. The number of exposed cells was estimated from $\mathcal{N}_{x}=\mathcal{N} /(1-\exp (-\mu))$, where $\mathcal{N}_{x}$ is the number of exposed cells, $\mathcal{N}=$ is the number of observed cells with at least one aberration and $\mu=$ mean number of aberrations per exposed cell. The expected frequency of exposed cells with 0 aberrations was estimated from $\mathcal{N}_{0}=\mathcal{N} \exp (-\mu) /(1-\exp (-\mu))$, where $\mathcal{N}_{0}=$ the expected frequency of exposed cells with 0 aberrations, $\mathcal{N}=$ the number of observed cells with at least one aberration, and $\mu=$ the mean number of aberrations per exposed cell. The expected frequency of exposed cells with 1 or more aberrations was estimated by multiplying the observed number of cells with at least one aberration by the probability of observing a given number of aberrations per exposed cell predicted from the 0 -truncated Poisson distribution; $\operatorname{Pr}(X=k)=\mu^{k} \exp (-\mu) /(1-\exp (-\mu) k$ !, where $\mu=$ mean number of aberrations per exposed cell and $k=$ number of aberrations per exposed cell.

†Variance/mean.

$\S$ From the $\chi^{2}$ test for goodness of fit after collapsing over cells to obtain an expected of at least 5.

【Expected number of exposed cells.

$\|$ Collapsing only over three and four aberrations per cell: $p=0.4$.

Table 4. Hprt mutant frequency (MF) among long-term American thorotrast* $(n=6)$ and diodrast $(n=5)$ survivors.

\begin{tabular}{|c|c|c|c|c|}
\hline ID & Contrast & Cloning efficiency (\%) & $\operatorname{MF}\left(\times 10^{-6}\right)$ & Mutants (no.) \\
\hline 1 & $\mathrm{~T}$ & 10 & 15.5 & 12 \\
\hline 2 & $\mathrm{~T}$ & 14 & 1.4 & 2 \\
\hline 3 & $\mathrm{~T}$ & 53 & 9.8 & 38 \\
\hline 5 & $\mathrm{~T}$ & 10 & 5.4 & 1 \\
\hline 7 & $\mathrm{~T}$ & 14 & 27 & 42 \\
\hline 8 & $\mathrm{~T}$ & 10 & 36.5 & 13 \\
\hline Median & & 12 & 12.6 & 12.5 \\
\hline Mean & & $18.4 \pm 17.1$ & $15.9 \pm 13.5$ & $18.0 \pm 17.8$ \\
\hline 9 & $\mathrm{D}$ & 12 & 16.6 & 15 \\
\hline 10 & $\mathrm{D}$ & 36 & 17.7 & 23 \\
\hline 11 & D & 9 & 8.6 & 3 \\
\hline 12 & $\mathrm{D}$ & 38 & 2.1 & 3 \\
\hline 13 & $\mathrm{D}$ & 50 & 25.0 & 85 \\
\hline Median & & 36 & 16.6 & 15 \\
\hline Mean & & $29.0 \pm 17.7$ & $14.0 \pm 8.8$ & $25.8 \pm 34.2$ \\
\hline$p^{\dagger}$ & & 0.6 & 1.0 & 0.6 \\
\hline
\end{tabular}

*Not determined for two Thorotrast survivors because of poor cloning efficiency $(4 \%)$ or technical problem.

$\dagger$ From the nonparametric Wilcoxon rank sum test.

An increased frequency of unstable chromosome aberrations in thorotrast survivors was noted. This class, which includes multicentrics and rings (Sasaki 1983), usually results in an unequal distribution of genetic material during mitosis and often yields daughter cells that are not viable. The marked increase in chromosomal abnormalities, reflected by the range of multicentrics and rings that were observed among the seven American thorotrast survivors $(0.002-0.138$ per cell), was similar to that 
observed among 63 Japanese thorotrast survivors (0.013-0.355 per cell). The frequency of multicentrics and rings among the diodrast group (0.002-0.008 per cell) was similar to the mean background frequencies reported among an older general population sample in Japan (0.0015 per cell; Tonomura et al. 1983) and an adult sample in America (dicentrics 0.0016, rings 0.0002; Bender et al. 1988).

The distribution of chromosomal aberrations in lymphocytes of thorotrast-exposed individuals has been observed to be overdispersed relative to the Poisson distribution (Sasaki et al. 1987, Littlefield et al. 1997). In this small sample of thorotrast survivors we also observed a greater number of cells with two or more multicentrics or rings than expected based on the Poisson distribution; among the diodrast group no more than one chromosomal aberration was observed per cell. Others (Sasaki et al. 1987) have proposed that the distribution of chromosomal aberrations in peripheral blood lymphocytes from Thorotrast-exposed individuals is more consistent with the 0-truncated Poisson distribution because the examined cells consist of a mixture of exposed and unexposed cells. Assuming that the exposure is uniform in the pool of exposed cells, we found that the 0 -truncated Poisson distribution better predicted the number of cells with one, two, or three or more unstable aberrations.

The hprt locus is frequently used to assess the extent of somatic mutations in vivo (Mendelsohn 1990). For a group of 48 normal adults, Davies et al. (1992) reported the hprt mutant frequency to range from 0.48 to 11.53 per million cells. Gender, smoking habits, alcohol, caffeine consumption, or X-ray exposure did not affect the frequency. The frequency, however, did increase with age $\left(0.09 / 10^{6}\right.$ cells $/$ year of age). No difference in hprt mutant frequency in peripheral lymphocytes between the thorotrast survivors and diodrast group was observed. The reason for the lack difference is unclear. However, highLET radiation is relatively more efficient in inducing large chromosome-type lesions and these will not be efficiently detected in the lymphocyte cloning assays that use the hprt gene. The induction of point mutations by thorotrast is possible, but is likely to be smaller compared to the overall spectrum of damage. Consistent with this, among the thorotrast survivors, a positive correlation, although not statistically significant, was noted between the frequency of multicentrics, but not rings, and the hprt mutant frequency.

This study is limited by the small number of surviving thorotrast-exposed patients available to provide blood samples for this analysis. The statistical power to determine if the distribution of unstable chromosome aberrations was inconsistent with the 0truncated Poisson distribution was limited. Only qualitative observations about differences in induction kinetics of different types of genetic damage could be made. We had little information on other endogenous and exogenous factors that might increase the burden of DNA damage independent of thorotrast exposure. Finally these participants who survived decades of internal $\alpha$-particle exposure may differ from those patients who developed exposureassociated fatal cancers, blood dyscrasias, or liver cirrhosis. Sources of variability might include distribution of the contrast medium to target organs, radiation dose delivered to susceptible tissue and inherent factors, such as DNA-repair efficiency and age at first exposure. These factors would likely affect the nature and extent of genetic damage resulting from thorotrast exposure.

\section{Acknowledgements}

This work was supported by a contract (N01-CP21151) with the National Institutes of Health. We appreciate the contributions of Zheng Fa Zuo, who performed the clonal assays, and Rosito Lamela, who prepared and scored the chromosomal aberrations. We express our gratitude to Dr Richard R. Monson for his thoughtful commentary. We also thank Dr John D. Boice, Jr, for his efforts to continue this research on the long-term effects of thorotrast.

\section{References}

Andersson, M., Carstensen, B. and Storm, H. H., 1995, Mortality and cancer incidence after cerebral arteriography with or without Thorotrast. Radiation Research, 142, 305-320.

Andersson, M. and Storm, H. H., 1992, Cancer incidence among Danish Thorotrast-exposed patients. Fournal of the National Cancer Institute, 84, 1318-1325.

Andersson, M., VyberG, M., Visfeldt, J., Carstensen, B. and Storm, H. H., 1994, Primary liver tumors among Danish patients exposed to Thorotrast. Radiation Research, 137, 262-273.

Bender, M. A., Preston, R. J., Leonard, R. C., Pyatt, B. E., Gooch, P. C. and Shelby, M. D., 1988, Chromosomal aberration and sister-chromatid exchange frequencies in peripheral blood lymphocytes of a large human population sample. Mutation Research, 204, 421-433.

Buckton, K. E., Langlands, K. L. and Woodcock, G. E., 1967, Cytogenetic changes following Thorotrast administration. International Fournal of Radiation Biology and Related Studies in Physics, Chemistry, and Medicine, 12, 565-577.

da Motta, K C., Horta, J., Da, S. and T avares, M. H., 1979, Prospective epidemiological study of Thorotrast-exposed patients in Portugal. Environmental Research, 18, 152-172. 
Davies, M. J., Lovell, D. P. and Anderson, D., 1992, Thioguanine-resistant mutant frequency in T-lymphocytes from a healthy human population. Mutation Research, 265, 165-171.

Fischer, P. and Golob, E., 1967, Chromosomal aberrations in thorium dioxide patients. Annals of the New York Academy of Sciences, 145, 759-766.

Fischer, P., Golob, E., Kunze-Mühl, E., Ben Haim, A., Dudley, R. A., Müllner, T., Parr, R. M. and Vetter, H., 1966, Chromosome aberrations in peripheral blood cells in man following chronic irradiation from internal deposits of Thorotrast. Radiation Research, 29, 505-515.

Goldman, M. B., Janower, M. L., Monson, R. R., Platz, E. A., Schottenfeld , D. and T Ravis, L. B., 1997, Liver cancer after long-term exposure to radioactive Thorotrast (abstract). American Foumal of Epidemiology, 145 (suppl), S68.

Ishihara, T., Kohno, S., HAYATA, I. and K UMATORI, T., 1978, A nine-year cytogenetic follow-up of a patient injected with Thorotrast. Human Genetics, 42, 99-108.

Janower, M. L., Miettinen, O. S. and Flynn, M. J., 1972, Effects of long-term Thorotrast exposure. Radiology, 103, $13-20$.

Kaul, A. and Noffz, W., 1978, Tissue dose in Thorotrast patients. Health Physics, 35, 113-121.

Kemmer, W., Muth, H., T ranekJer, F. and Edelmann, L., 1971, Dose dependence of the chromosome aberration rate in thorotrast patients. Biophysik, 7, 342-351.

Kemmer, W., Steinstrasser, A. and Muth, H., 1979, Chromosome aberrations as a biological dosimeter in Thorotrast patients: dosimetric problems. Environmental Research, 18, 178-183.

Littlefield, L. G., T Ravis, L. B., Sayer, A. M., Voelz, G. L., Jensen, R. H. and Boice JR, J. D., 1997, Cumulative genetic damage in hematopoietic stem cells in a patient with a 40-year exposure to alpha particles emitted by thorium dioxide. Radiation Research, 148, 135-144.

Mendelsohn, M. L., 1990, New approaches for biological monitoring of radiation workers. Health Physics, 59, 23-28.

Mori, T., Kato, Y., Kumatori, T., Maruyama, T. and H ATKAKEYAMA, S., 1983, Epidemiological follow-up study of Japanese Thorotrast cases-1980. Health Physics, 44, $261-272$.
Rosner, B., 1986, Fundamentals of Biostatistics (Boston: Duxbury Press).

SASAKI, M. S., 1983, Use of lymphocyte chromosome aberrations in biological dosimetry: possibilities and limitations. In Radiation-Induced Chromosome Damage in Man, edited by T. Ishihara and M. S. Sasaki (New York: Alan R. Liss), pp. 585-604.

Sasaki, M. S., T aKatsuji, T., Ejima, Y., Kodama, S. and Kido, C., 1987, Chromosome aberration frequency and radiation dose to lymphocytes by alpha-particles from internal deposit of Thorotrast. Radiation and Environmental Biophysics, 26, 227-238.

Steinstrasser , A., 1981a, Biophysical investigations of the doseeffect relationship in chromosome aberrations of human lymphocytes caused by Thorotrast deposits. I. Physical aspects. Radiation and Environmental Biophysics, 19, 1-15.

Steinstrasser , A., 1981b, Biophysical investigations of the doseeffect relationship in chromosome aberrations of human lymphocytes caused by Thorotrast deposits. II. Biological and medical aspects. Radiation and Environmental Biophysics, 19, 17-28.

Teixeira-Pinto, A. A. and Azevedo e Silva, M. C., 1979, Chromosome radiation-induced aberrations in patients injected with thorium dioxide. Environmental Research, 18, 225-230.

T Onomura, A., Kishi, K. and SAito, F., 1983, Types and frequencies of chromosome aberrations in peripheral lymphocytes of general populations. In Radiation-induced Chromosome Damage in Man, edited by T. Ishihara and M. S. Sasaki (New York: Alan R. Liss), pp. 605-616.

Travis, L. B., Kathren, R. L. and Boice Jr., J. D., 1992, Cancer risk following exposure to Thorotrast: overview in relation to a case report. Health Physics, 63, 89-97.

van Kaick, G., Lieberman, D., Lorenz, D., Lorenz, W. J., LÜHrs, H., Scheer, K. E., Wesch, H., Muth, H., K AUl, A., Immich, H., W Agner, G. and Wegener, K., 1983, Recent results of the German Thorotrast study-epidemiological results and dose effect relationships in Thorotrast patients. Health Physics, 44 (suppl 1), 299-306.

van Kaick, G., Wesch, H., Lührs, H., Liebermann, D. and K AUl, A., 1991, Neoplastic diseases induced by chromic alpha-irradiation-Epidemiological, biophysical and clinical results of the German Thorotrast Study. Fournal of Radiation Research, 2(suppl), 20-33. 